Session 2478

\title{
An Intercampus Graduate School of Marine Sciences and Technology
}

\author{
Eugene E. Niemi, Jr. \\ University of Massachusetts Lowell
}

\section{Introduction}

Four of the colleges that make up the University of Massachusetts system are working together to establish an Intercampus Graduate School of Marine Sciences and Technology (IGS). The Lowell campus, often considered the technology campus of the UMass system, will provide much of the groundwork for the marine engineering portion of the program. The overall purpose of the IGS program is to offer a course of study in marine sciences integrating the natural and social sciences in a manner not offered by established academic institutions in the New England region, or for that matter, in much of the country. The availability of courses, laboratories, and supervising faculty from four campuses provides students with a greater range of choices than is currently available at a single campus. The organization of the school and the courses to be offered are described. Each of the campuses of the UMass system (Amherst, Boston, Dartmouth, and Lowell) brings individual strengths to the program. The core courses in the program are described together with the areas of specialization available at each campus. A description of how fluid mechanics and ocean engineering courses offered at the Lowell campus will be integrated into the new program are described. The curriculum is currently in the developmental phase and will be in place for the first class of students enrolling in the Fall of 2001. The program fills a need for an offering of this type by a university in the public sector.

\section{Goals}

The IGS will offer education at the MS and $\mathrm{PhD}$ level to prepare students to work in areas of marine sciences and technology in industry, government, and academic settings. During the first five years of its operation, the IGS will strive to become a nationally and internationally recognized educational center of excellence contributing to scientific understanding, management, and the economic growth and sustainability of our oceans, continental shelf, coastal zone, and the communities of Massachusetts that border the ocean. It will do this through the creation of a graduate program that builds on the strengths of four of the campuses of the UMass system (Amherst, Boston, Dartmouth and Lowell).

\section{Graduate School Curriculum}

"Proceedings of the 2001 American Society for Engineering Education Annual Conference \& Exposition, Copyright (C) 2001, American Society for Engineering Education” 
At the present time, sixty-eight faculty and professional staff from the four campuses have affiliated with IGS based on application and approval of their qualifications. In addition, seventy-four existing courses already taught on the four campuses have been approved for offering through the IGS curriculum. More specialized courses, including four core courses, will be developed over the next few years.

Although each student will have a "resident campus," students are encouraged to take courses on more than one campus, and numerous courses, especially the core courses, will be offered by distance learning to make them available to all campuses. The logistics of the program requirements are somewhat traditional and follow.

The MS program will require a minimum of 30 semester hours of study and can be done in a thesis or non-thesis option. Four courses (12 credits) come from a common core, and the remainder are selected in an area of concentration approved by the student's major advisor and committee. The MS program will normally be completed in two years of study, and each student must present one seminar in the third or fourth semester. Thesis students will write a thesis and present a public thesis defense followed by an oral examination by the thesis committee. Nonthesis students will prepare a research paper that must be read and approved by the student's advisor and one other faculty member.

In addition to MS course requirements, $\mathrm{PhD}$ students must complete an additional minimum of 24 - 30 credit hours of course work in a concentration area. Written and oral candidacy examinations must be passed. A dissertation committee is established and a written dissertation proposal is required. The dissertation committee must include at least one IGS faculty member from a campus other than the student's resident campus. All candidates for the PhD degree must do scholarly research and write a dissertation followed by a public defense and an oral examination by the candidate's dissertation committee.

Core courses of study Both the MS program and the $\mathrm{PhD}$ program will require the following four core courses:

$\begin{array}{ll}\text { Biological Oceanography } & 3 \text { credits } \\ \text { Chemical Oceanography } & 3 \text { credits } \\ \text { Physical Oceanography } & 3 \text { credits } \\ \text { Policy/Management } & 3 \text { credits }\end{array}$

Students will normally be expected to complete all the core courses in their first two semesters of study.

Curriculum concentrations Currently, seven concentrations have been planned for the program. These are (1) Integrated Coastal Management, (2) Ocean and Human Health, (3) Living Marine Resources Science and Management, (4) Marine Biogeochemical Cycles and Environmental Change, (5) Analysis and Modeling of Marine and Atmospheric Systems, (6) Coastal Systems Science, and (7) Marine Observation Technologies. Areas (5) and (7) will include more of the traditional ocean engineering courses, and will be supported by the Lowell campus. A detailed description of topics covered in each of these areas can be found in Ref. 1.

\footnotetext{
"Proceedings of the 2001 American Society for Engineering Education Annual Conference \& Exposition, Copyright (C) 2001, American Society for Engineering Education”
} 
Sequence of courses by semester All graduate students will be expected to complete the four core courses in the first two semesters of their program. In the first year, besides the core courses, all students will register for a marine science and technology seminar series. Full time students will register for a minimum of three courses ( 9 credits) plus the marine science and technology seminar (1 credit) each semester. Electives in the student's area of concentration will be selected with the approval of the student's advisor. The tables to follow summarize the course sequence for the duration of the program. Table 1 outlines the first two semesters.

Table 1. Semesters 1 and 2

\begin{tabular}{|l|l|l|}
\hline Course & Semester $\mathbf{1}$ & Semester $\mathbf{2}$ \\
\hline Two core courses & 6 credits & 6 credits \\
\hline One elective & 3 credits & 3 credits \\
\hline Seminar series & 1 credit & 1 credit \\
\hline Total (20 credits) & 10 credits & 10 credits \\
\hline
\end{tabular}

MS students will usually complete all degree requirements in four semesters. A typical course sequence for the third and fourth semesters for MS students is shown in Table 2.

Table 2. MS student semesters 3 and 4

\begin{tabular}{|l|l|l|}
\hline Course & Semester $\mathbf{3}$ & Semester $\mathbf{4}$ \\
\hline One elective (minimum) & 3 credits & 3 credits \\
\hline Thesis or non-thesis & $1-6$ credits & $1-6$ credits \\
\hline Seminar series & Required - no credit & Required - no credit \\
\hline Total (10+ credits) & $3+1$ to 6 credits & $3+1$ to 6 credits \\
\hline
\end{tabular}

$\mathrm{PhD}$ students will usually complete the additional concentration coursework (24-30 credits) by the end of the fifth semester, since they do not do a Master's thesis. Written and oral candidacy examinations should be completed no later than the sixth semester. A typical PhD sequence of courses for semesters three through five is shown in Table 3.

Table 3. PhD student semesters 3 through 5

\begin{tabular}{|l|l|l|l|}
\hline Course & Semester $\mathbf{3}$ & Semester $\mathbf{4}$ & Semester $\mathbf{5}$ \\
\hline Electives & 9 credits & 9 credits & 9 credits \\
\hline Seminar series & Required - no credit & Required - no credit & Required - no credit \\
\hline Total (24-30 credits) & 9 credits & 9 credits & 9 credits \\
\hline
\end{tabular}

After advancing to candidacy, $\mathrm{PhD}$ students will normally register each semester for dissertation

"Proceedings of the 2001 American Society for Engineering Education Annual Conference \& Exposition,

Copyright (C) 2001, American Society for Engineering Education” 
research (1-9 credits) until graduation.

Although the sequence of progression through the program is somewhat traditional, it is emphasized that the uniqueness of the program lies in its interdisciplinary nature, both in required coursework and in the availability of courses across the four campuses.

\section{Current Campus Strengths}

There are several programs already in existence at each campus that will provide the backbone for the IGS curriculum. Brief descriptions of some of these programs and the facilities already in existence at each campus are as follows.

Amherst: The Amherst campus has a number of departments and programs that emphasize marine science. Among these are the Department of Natural Resources Conservation and the Department of Geosciences. Research activities in Natural Resources include graduate level work in marine fisheries and mammals, and coastal zone management. Undergraduate and graduate level courses in oceanography can be taken in the Department of Geosciences. Students can participate in ongoing field programs providing ship-board research experiences through the Five College Coastal and Marine Program and the Sea Education Association at Woods Hole Oceanographic Institute.

Boston: The Boston campus already has a graduate Department of Environmental, Coastal and Ocean Sciences (ECOS) that provides cross-disciplinary graduate training in coastal and ocean related social and natural sciences. Between this department and the Biology Department, there are currently 60 students (equally divided between MS and PhD programs) being trained for key marine-related positions in government, industry and academia. Research projects include an undulating towed vehicle known as ECOShuttle that allows researchers to obtain high resolution distributions of chemical, physical, and biological parameters to study complex processes in the ocean. Researchers at the Boston campus are also working on miniaturizing laser based sensors for incorporation into autonomous underwater vehicles for long term monitoring of the ocean.

Dartmouth: Eleven departments are involved in teaching and research programs in marine sciences and technology at this campus. A graduate program in electrical engineering oriented towards marine sciences and technology is one of these. This program offers both MS and PhD degrees. A recently established School for Marine Sciences and Technology (SMAST) is conducting systems approach research dealing with many aspects of the ocean. Other programs under the auspices of the Dartmouth campus include the Fisheries Assessment and Management Program, the Ocean Prediction and Monitoring Program, and the Ocean Communications, Tracking and Control Program. The Ocean Prediction and Monitoring Program uses sensors to track changes in biological, chemical and physical properties of the coastal zone in the northeast United States. As one of its functions, this program has recently expanded the Harvard Ocean Prediction System to include the shallow water regions of the Gulf of Maine and the western North Atlantic Ocean. The Ocean Communications, Tracking and Control Program utilizes lasers, underwater acoustics, and electromagnetic radiation to improve working in the ocean. Unmanned underwater vehicles are being developed for marine exploration, survey, and

"Proceedings of the 2001 American Society for Engineering Education Annual Conference \& Exposition, Copyright (C) 2001, American Society for Engineering Education” 
monitoring in conjunction with the Naval Undersea Warfare Center.

Lowell: The Lowell campus is often referred to as the technology campus of the UMass system. It has several departments and centers involved in marine science and technology related work. Among these are the Department of Environmental, Earth and Atmospheric Sciences; the Center for Environmental Engineering, Science and Technology; the Center for Atmospheric Research; and the Toxics Use Reduction Institute. Through the Civil Engineering Technology Program, hundreds of wastewater plant operators have been trained, and the Mechanical Engineering Department has been involved in ocean engineering courses and research in past years. Lowell's contribution to the ocean engineering portion of the IGS curriculum is through its coursework and research experience in ocean engineering. The Lowell campus has conducted extensive research on oil spills on water, both through the Chemistry Department and the Mechanical Engineering Department. The Chemistry Department's emphasis has been on methods of gelling oil spills ${ }^{2,3}$ so they could be swept up by surface ships, while the Mechanical Engineering Department's emphasis has been on investigating oil spill dispersion rates ${ }^{4,5}$ on the ocean in different sea states. The Department has also offered a course called Mechanical Engineering Problems in Oceanography from time to time. The development of the IGS will give the department the opportunity to offer ocean engineering related courses once again and to offer them to all campuses through distance learning. Also offered are courses in fluid mechanics, advanced fluid mechanics, and viscous flow, using a textbook ${ }^{6}$ written by one of the professors in the Mechanical Engineering Department.

\section{Transitional Curriculum}

The four core courses will be newly developed and first offered beginning in 2003-2004, and will be "designed to insure that IGS students learn key concepts that are necessary for an interdisciplinary marine sciences and technology graduate program." 1 The new core courses will all be taught via distance learning to insure their availability to students on all four campuses. Concentration courses will be offered on the individual campuses, but many will be offered to the other campuses through distance learning also.

During the first and second years of the curriculum development (2001-2002, and 2002-2003), the required core courses may be satisfied by students selecting from a number of existing options offered to them from a "Master Course Matrix." This will allow "charter" students to satisfy core course requirements from courses already in existence on the four campuses, while the new core courses are being developed. For example, on the Amherst campus, the Policy/Management core course can be satisfied by selecting either Coastal Resource Policy or International Environmental Politics. On the Boston campus, the Biological Oceanography core course can be temporarily satisfied by selecting either Biostatistics or Biological Oceanographic Processes. On the Dartmouth Campus, the Physical Oceanography requirement can be satisfied with either of the existing courses Fundamentals of Physical Oceanography or OceanAtmosphere Dynamics. On the Lowell campus, the Chemical Oceanography core course can be satisfied for the time being by taking Environmental Chemistry III (Marine Chemistry). In a similar manner, by a proper selection of on-campus or distance learning courses, students on any of the four campuses can satisfy the core requirements while the new core courses are being prepared. "Proceedings of the 2001 American Society for Engineering Education Annual Conference \& Exposition,
Copyright (C) 2001, American Society for Engineering Education" 
The engineering courses offered on the Lowell campus will be used primarily to satisfy concentration requirements in the two concentration areas of Analysis and Modeling of Marine and Atmospheric Systems, and Marine Observation Technologies.

\section{Administration of the IGS Program}

The IGS is headed by a Dean and an Associate Dean who are appointed by the University Vice President for Academic Affairs, in consultation with leadership from the four campuses. In its initial formation, the IGS is headed by Dean Brian Rothschild from the Dartmouth campus and Associate Dean Jack Archer from the Boston campus.

The most important committee is the Intercampus Oversight Committee, which consists of two representatives from each campus and the University Vice President for Academic Affairs. Each campus has one representative who is an administrator, and one who is a faculty member. This committee, as its name implies, has responsibility for oversight of the program, and to insure that each campus is adequately represented in decisions regarding the program. Other committees of a more traditional nature also exist and operate in a manner typical of any academic program.

\section{Conclusions}

A description has been given for a new graduate school program in Marine Sciences and Technology. This program is interdisciplinary in nature and builds on the strengths and capabilities of existing programs on four campuses of the University of Massachusetts system. The Lowell campus will provide much of the experiential resources in ocean engineering. The choices available to the students in this manner will insure that the program fulfills its stated objective of becoming a nationally recognized educational center of excellence in Marine Technology.

\section{Acknowledgement}

The author wishes to thank the following two individuals for the great deal of effort they put into the preparation of the proposal for this new program, and from which much of the material for this paper is taken: Dr. Jack H. Archer, Associate Dean, IGS, and Associate Dean, Office of Graduate Studies and Research, Boston Campus; and Dr. Brian J. Rothschild, Dean, IGS, and Director, School of Marine Sciences and Technology, Dartmouth Campus.

\section{References}

1. Archer, J. \& Rothschild, B., Final Application for the MS and PhD Degree Programs in Marine Sciences and Technology, University of Massachusetts, September 2000.

2. Bahloul, S. K., Donatelli, Bannister, and Walkinshaw, "Gellants for Control of Petroleum Spills on Water," I \& EC Product Research and Development, 1979, v 18, pp 364-367.

3. Bannister, W. H., Donatelli, Curby, Kan, Dalton, and Porta, "Facilitating Spill Control and Recovery," Marine Technology, October 1980, pp 146-149.

4. Ramberg, S.E., "Experimental Study of Spreading Rate of Oils on Still Water," MS Thesis, Mechanical

"Proceedings of the 2001 American Society for Engineering Education Annual Conference \& Exposition, Copyright (C) 2001, American Society for Engineering Education” 
Engineering Dept., Lowell Technological Institute (now University of Massachusetts Lowell), Lowell, MA, October 1972.

5. Donnelly, P.F., III, "Experimental Study on the Effects of Waves on Spreading Rate of Oil," MS Thesis, Mechanical Engineering Dept., Lowell Technological Institute (now University of Massachusetts Lowell), Lowell, MA, May 1973.

6. Mironer, A. Engineering Fluid Mechanics, McGraw-Hill Book Co., New York (1979).

\section{EUGENE E. NIEMI, JR.}

Eugene Niemi is Professor of Mechanical Engineering at the University of Massachusetts Lowell. He received the $\mathrm{PhD}$ in Mechanical Engineering from the University of Massachusetts at Amherst. He teaches courses in fluid mechanics, heat transfer, and aerodynamics. Prior to coming to Lowell, he worked on steam turbines for shipboard use at GE, and on guided missiles at Raytheon. He was advisor to the Human Powered Submarine project at Lowell that competed successfully in trials in San Diego in 1996.

"Proceedings of the 2001 American Society for Engineering Education Annual Conference \& Exposition, Copyright (C) 2001, American Society for Engineering Education” 